\title{
The Impact of Different Teaching Strategies on Teaching Grammar to College Students
}

\author{
Ali Hashemi \\ Faculty of Humanities, University of Zanjan, Zanjan, Iran \\ Samran Daneshfar \\ Faculty of Humanities, University of Zanjan, Zanjan, Iran
}

\begin{abstract}
Grammar is considered critical to the ability to use language. Grammar teaching is an issue that provokes strong feelings and attitudes. Grammar teaching is particularly prominent in English as a foreign language (EFL) settings as it is perceived that without a good grammar knowledge, language development will be seriously inhibited. In the current study, we used three grammar instruction techniques including "the Deductive Technique", "the Inductive Technique", and "the Implicit Technique". 80 college students, studying different fields in Abbar, Zanjan, participated in the study. They were assigned to three experimental groups for each of the three teaching techniques. The Deductive group consisted of 31 law students, both boys and girls, the Inductive group comprised 27 boy and girl accounting students, and there were 28 IT students in the Implicit group. The results of data analysis indicated that these groups performed differentially in certain respect. Meanwhile, the Inductive group exceeded the other groups in their performance.
\end{abstract}

Index Terms - grammar, theories of grammar, grammar teaching, implicit knowledge, deductive knowledge, inductive approach

\section{INTRODUCTION}

Grammar teaching and learning, in the past years, has experienced a drastic change. The prominent position and prestige that grammar once enjoyed, in the traditional context of language teaching, is replaced by almost complete negligence in modern innovative approaches. Grammar which held the central component of language instruction in the past, is now being frowned upon and holds no place in communicative approaches. Grammar instruction arouses mixed and even opposite attitudes and it is also one of the difficult aspects of language to teach well.

\section{REVIEW OF THE RELATED LITERATURE}

\section{A. Definitions of Grammar}

There exists a number of different assumptions and theories regarding the concept of grammar which indicate the influence by the underlying approaches (Ellis, 2006; Purpura, 2004). A looking at these definitions illustrates the ambiguity present in these assumptions. Grammar is the system or the rules of a language. David Crystal (1995) views grammar as the business of taking a language to pieces, to see how it works. In the same way, Penny (2000) thinks of grammar as agreed upon rules that delineate how words are combined to produce acceptable meaningful language units. However, grammar in a broader sense, is taken to mean: "an internal mental system", "a set of prescriptions of language forms", "a description of language behavior", "the major structures of a language", and finally "rules for instructional and assessment purposes " (Larsen-Freeman, 2009).

Linguists consider the concept of grammar in a very specific sense. In linguistics' point of view, grammar is a set of internalized rules speakers use for generating and interpreting language. In this sense, grammar is mostly acquired and not learned by instruction and conscious training. To Richards (1992), grammar is the organization of a language; it is the manner by which units of language like words and phrases are combined to form sentences. In line with Richards, Wales (2001) defines grammar as the language element, specially the words, phrases and clauses that build sentences. Thus, grammar is the set of rules specifying the correct ordering of words at the sentence level (Nunan, 2003) or, similarly, the rules that govern how sentences are formed in a specific language (Thornbury, 2008).

\section{B. The Importance of Grammar}

Grammar is a framework for the analysis and description of languages. Grammar is of key significance for accuracy and correct language usage. It can act as an enabling skill and motivate students to some extent in their path to proficiency. Today, due to widespread use of tests as means of entering institutions, programs, as well as higher level education, which require the participants to act and perform accurately in these situations, students are expected to familiarize themselves with correct grammar. Thus, it necessitate for the educator to include grammatical proficiency as part of the curriculum. Meanwhile, without a good knowledge of grammar, clear and effective communication may 
not be possible. Good knowledge of grammar is usually a sign of education and poor communication skills will lead to the formation of negative impressions in the interlocutors. In addition, correct writing and speaking confers you confidence and credibility. If you are spirant for great dreams and a higher professional reputation, it is of remarkable significance.

Grammatical rules, Ur (1999) believes, enable learners to know how sentence patterns work. Accordingly, grammar should center on the correct use of structural items or sentence patterns. Thus, grammar instruction covers the structure or sentence patterns of the language. Meanwhile, grammar is underlies other language skills like reading, speaking and writing. In speaking grammar is greatly important for producing grammatically acceptable forms in the language (Corder, 1988). Thus, the role of grammar is important in language teaching to prepare communicative tasks. This is the same as Doff (2000), claim where he holds that students can convey meanings through phrases, clauses and sentences.

\section{Traditional Approaches to Language Teaching}

The prime example of the traditional language teaching was the Grammar-Translation method. Grammar-Translation dominated language teaching and instruction for so a long time. In this method explicit grammar teaching was the core constituent. They gave prominence to grammar that was considered all important and formed the central part of language learning. The leading learning activity, then, involved grammatical analysis and translation of written forms (Herron, 1976; Howatt, 1984; Rutherford, 1987).

The Grammar-Translation method which was primarily developed for the teaching of the classical languages of Greek and Latin, divided language into different parts to be learnt separately. The learner was supposed to practice decontextualized forms of language. The foremost features of the method involved explicit teaching of grammatical rules, memorization of vocabulary lists, emphasis on written and not spoken language, the authority of the teacher, and translation from and into the target language. Under the Grammar-Translation method, students gained wide grammatical knowledge of the language but little communicative ability.

The traditional teaching method helped the students master the grammatical forms. However, the students were not able to use these rules in communication. Thus, the traditional method has some drawbacks. First, it was teacher-centered; the teacher is active while the learner is completely passive. Second, memorization and mechanical learning are the basic learning activities, which are by no means effective to provoke students' attention, shape their confidence, or develop their strategies in English learning and even makes them fear grammar learning (Chang, 2011).

The Audiolingual method which was a reaction against the Grammar-Translation method, stressed the development of the spoken language. However, spoken language was broken into discrete parts and presented in structured sequences of forms. Language was analyzed through different subsystems (Larsen Freeman \& Long, 1991): phonology, morphology, and syntax. This is in line with the approach called structural or descriptive linguistics.

Audiolingualism adhered to the structural school of linguistics which considered language learning as the formation of correct habits. Classroom learning and teaching activities included repetition of models and memorization of dialogues. The purpose of these activities is to produce the target language as correctly as possible. Consequently, the final product of learning was accuracy. Thus, errors were detrimental to the flow of learning and were viewed as bad habits to be corrected at once (Celce-Murcia, 1991).

\section{Prescriptive and Descriptive Grammar}

Prescriptive grammar involves the correct use of language. It deals with what is grammatical and what is not grammatical and, therefore, should be avoided. A prescriptive grammar tells you how you should speak. It is a type of pedagogical grammar where the goal is to teach people how to use language in a proper or correct way. Prescriptive grammar, for example, requires that split infinitives be not used as they are improper or incorrect.

Descriptive grammar deals with describing the mental grammar, or the language as it is used by native speakers, not how it should be used. The difference between these two is that descriptive grammar states that a sentence is grammatical if it is produced by a native speaker, but for a prescriptive grammarian, a sentence is grammatical only if it follows certain grammatical rules. Thus, for the prescriptive grammarian surface form is very important than language in real context.

\section{E. Deductive and Inductive Teaching}

In deductive teaching, the rules are explicitly presented to the learners, which then are applied to produce specific examples based on the rule. After the presentation phase of the grammar rule, the learner engages with it through the study and manipulation of examples. This technique has been favored in language teaching and still dominates many course books and self-study grammar books (Fortune, 1992).

In inductive approach, the learners are presented with concrete examples of the given rule and, in return, they work out to discover the rules for themselves. This is a kind of discovery learning which involves some process of reasoning and inference. It is stated that the teacher starts teaching grammar with presenting examples and the learner discovers or induces the rules relating to the examples.

\section{F. Implicit vs. Explicit Teaching}


In teaching and learning, it is useful to know that there are two types of knowledge help gain language proficiency. They are referred to as explicit (conscious learning) and implicit (subconscious acquisition) knowledge (Klein, 1986).

To Ellis (2004), explicit knowledge is conscious knowledge of grammatical rules learned through formal classroom instruction, and is related to the conscious uses to language. Explicit knowledge helps intake and expansion of implicit language, as well as monitor output (Krashen, 1987). Brown (2000) views explicit knowledge as knowing about language and the ability to articulate those facts.

Implicit knowledge, to Brown (2000), is internalized, subconscious language knowledge accessible in the course of spontaneous language tasks. It can be attained through natural exposure to the language. This is the case in first language acquisition where the native speaker cannot consciously verbalize the rules governing the language.

A more balanced view: a judicious combination of both the explicit and the implicit grammar teaching techniques can be utilized to teach grammar forms. I mean that in the first phase, the teacher lets the students discover the rules for themselves implicitly. This is a problem solving technique which is profoundly beneficial to the learner to make his self-constructed version of form. After this initial phase, the teacher explicitly intervenes to provide further explanation and correct any misconceptions or wrong conclusions students have drawn.

\section{G. Grammar Teaching}

There has been strong controversy over the issue of grammar teaching in language learning, and some of the problems still persist. Teaching grammar is traditionally (Ur, 1996; Hedge, 2000) regarded as presenting and practicing specific grammatical points. However, this is a limited view of teaching grammar as grammar teaching and instruction can occur naturally by exposing learners to certain forms while focusing on the message in the accomplishment of some communicative tasks.

In EFL settings, grammar-translation has traditionally ruled grammar teaching. Larsen-Freeman (2000) observes that in such a method, native language is used to elicit meaning and translation from the target language into the native language constitutes the main classroom activity. In this method grammatical forms and vocabulary of the target language are deductively presented to the learners, and the learner, in return, is required to memorize them (Richards $\&$ Rodgers, 2001).

Some experts, for example Long (1983), Krashen (1987), and Swain (1985), believe that L2 acquisition reflects similar processes involved in L1, but research indicates that mere exposure cannot lead to the development of grammatical competence. As a result, form-focused instruction was incorporated into the language instruction programs. It is now a commonly accepted belief (White 1987; Ellis 2006; Van Patten 2004) that, while conveying the intended message is the final goal, teaching grammar should form a part of classroom activities.

\section{H. Grammar Teaching Approaches}

\section{Traditional grammar teaching}

Language teaching has traditionally focused on studying the classic languages of Greek and Latin, and mainly grammatical analysis of written forms. Grammar-translation embodies this approach. In this method explicit grammar teaching was the core constituent. They gave prominence to grammar that was considered all important and formed the central part of language learning. The leading learning activity, then, involved grammatical analysis and translation of written forms. The final product of this methodology was learners that, although having extensive knowledge of the grammatical rules of the language, were unable to use the language in unrehearsed communicative contexts.

\section{Structural grammar and audio-lingualism}

Structuralism was a reaction against to the grammar-translation method of language instruction. Structural or descriptive approach focused on the analysis of the sound system of the language, and dealt with language analysis in three parts (Larsen Freeman \& Long, 1991): phonology, morphology, and syntax. Subsequently, structuralism was mixed with, then influential theory, behaviorism. The fusion led to the emergence of audio-lingualism which focused on the direct language learning to develop spoken fluency. The spoken language was in the form of oral drills, repetition and practice of language forms. Contrastive analysis of the two languages recognized areas of difficulty which formed the basis for the selection and presentation of teaching material. The goal was to attain accuracy and, consequently, errors were avoided at all cost as they led to the development of bad habits.

\section{Functional approach}

Functional syllabus was based on the learner's communicative needs. Functions determined the organization of the forms necessary for performing a specific communicative needs. Functional approach, which currently forms the basis of many language learning textbooks, is synthetic (Long and Crookes, 1992), and uses the three Ps syllabus (Skehan, 1998): presentation, practice, and production.

\section{Universal Grammar}

Rejecting the behavioristic habit formation view of the structural linguistics, Chomsky (1957) coined Universal Grammar. Universal grammar was certain generalizations and underlying assumptions that could be applied to all languages.

To Chomsky, language is a syntax- based generative inborn capacity in the human brain consisting of a surface structure and a deep structure. Chomsky made a distinction between competence, underlying language knowledge, and performance, the actual realization of that knowledge in practice (Cook, 1994). 


\section{Cognitive theory}

Chomsky's emphasis on universal grammar and syntax led to the revival of the explicit grammar teaching. Grammar instruction, thus, focused on deductive learning and language development was considered as mental processes, as involved in any learning, to attain language competence. This new trend formed the basis of cognivitism. Cognitive theorists hold that human beings do not come into the world as blank slates; they bring innate knowledge that help acquire their language on a rule governed basis.

Cognitive view of language instruction justifies explicit grammar teaching. Norris and Ortega (2000) support the idea that explicit grammar teaching promotes language learning; learners, using cognitive comparison of the input they receive and the output they produce, can learn more effectively.

\section{Communicative language teaching}

Krashen's emphasis on natural language acquisition through communication as well as his emphasis on exposure and the comprehensible input in the form of meaningful learning, paved the way for the communicative language teaching. Communicative language teaching discards explicit grammar instruction and emphasizes on the presentation of language forms in the context of meaningful real communication on the assumption that learners can acquire the form naturally while focusing on the message. Communicative language teaching is humanistic and delays error correction to build the confidence of the learner, create a positive feeling avoid embarrassment and anxiety in the learner.

Krashen (Krashen \& Terrell, 1 983) holds that explicit grammar teaching is not needed to develop correctness and learners can acquire language through exposure. However, research (Brown, 1994; Larsen-Freeman, 1991) fails to support the claim; grammatical competence is considered necessary for communication, but it is impossible in exposure. Meanwhile, in order to achieve essential communicative skills for social and academic success, instruction is deemed as necessary (Scarcella, 2003).

\section{Form-focused instruction}

Neither the grammar-translation method nor the communicative method could provide the solution for limitations in grammar teaching (Long, 1991). It was stated that the traditional syllabus (teaching certain discrete decontextualized grammar forms), and the communicative syllabus (neglecting the teaching of grammar) were not able to produce communicative competence (Skehan, 1996). To meet the objectives of an effective language instruction, form- focused instruction emerged. Focus on form was a way round this problem.

Focus on form is not the traditional explicit grammar teaching method. Long (1991) regards focus on form as an approach where primary focus is on meaning and communication with the learner only incidentally attends to linguistic elements. Focus on form recommends implicit language instruction. Focus on form is the planned or incidental integration of grammatical forms into the stream of language functions during the meaningful communication aiming to prompt language learners to pay attention to linguistic form (Ellis, 2001).

\section{Noticing and consciousness raising}

Grammar teaching is currently, (Schmidt, 1993; Skehan, 1998), viewed as consciousness raising meaning that specific feature is developed by formal instruction even if the learners cannot use the feature at once. This consciousness raising can also occur, in addition of formal instruction, by means of communication and interaction (Sharwood Smith, 1993). Of course, this is not the case in EFL situations where exposure to the target language is not possible and the learner cannot find any opportunities to interact with L2 speaker and internalize grammar rules.

According to Ellis (1996), as consciousness raises, either through formal instruction or communicative exposure, the learner notices the feature in the input. Noticing the feature in the sample leads to unconscious awareness of it and this very rule or feature restructures the learner's linguistic knowledge (Schmidt, 1990).

\section{An Effective Framework for Grammar Teaching}

Grammar is not a discrete skill to be acquired per se. Grammar instruction should form part of the whole of meaningful communication in real context. The purpose of grammar teaching is to facilitate communication. To satisfy this need, we should consider the following:

- Instruction should be provided in a way to link grammar forms to communication context.

- Only those forms that are more involved in the performance of the intended task are of primary significance.

- The instructor should try to invest the learner with personalized instruction to make sure of intake.

- An optimum level of error correction should be employed so as to maximize input while minimizing embarrassment.

Some traditionally-oriented language teachers tend to teach grammar by explaining the form and then make students drill and practice that form. This leads to good and correct performance in tests, but poor performance in communication. On the other hand, some teachers do not teach grammar at all and think that overt grammar instruction is not needed. Based on my experience in grammar teaching especially in EFL context, both in schools and colleges, I have come up with the following procedure which is both practical and efficient:

- We should be careful not to separate the grammar forms and the communication context.

- Use a variety of grammar instruction techniques to enforce learning.

- The teacher could develop his own text to meet the requirements of the teaching context and personalize teaching and learning.

- Students should be helped further to apply learnt rules to express new meanings. 
- Model the application of the rule so that learners could have clear ideas of how it works.

- Check students' understanding and comprehension of the application of the rule.

- Provide ample opportunities and situations for meaningful practice of the rule.

\section{J. Error Correction}

Considering the correction of erroneous learner utterances, most experts prescribe the use of a balanced view; neither too much instant correction nor the total neglecting of the errors. In order to have an optimum level of error correction, the researcher recommends delayed correction. Delayed correction requires that the teacher corrects errors in way to avoid frustration and break the flow of communication. Meanwhile it is to be implemented so that errors are not fossilized. The learner should be provided with adequate time to self-correct. Self-correction is of the utmost importance. To achieve this aim, the instructor calls student's attention to the error and strives to lead the learner to, by pointed remarks and explanation, to the correct response.

\section{METHOD}

\section{A. Participants}

80 college students from three university centers in Tarom, Zanjan were selected to participate in this study. These students were roughly at the same age range, from 19 to 21 , consisting of both boys and girls. The only prior experience they had in the English language instruction was at high school. All the participants were fluent Persian speakers, but most of them were bilinguals and could understand both Turkish and Persian and only a minor group of them was able to understand Tati, a native language spoken in some parts of Tarom.

These students were studying different fields including law, accounting, and IT. They were randomly assigned to three experimental groups, for the three techniques used in this paper. The Deductive group consisted of 31 law students, both boys and girls, the Inductive group comprised 27 boy and girl accounting students, and there were 28 IT students in the Implicit group.

\section{B. Instrumentation}

\section{Pre-test}

Due to the lack of a standard test for our goal, the researcher designed a test. A battery of tests was implemented to collect the required data. The initial test was a test of general English proficiency. The pre-test was pilot studied to improve any probable weaknesses. This pre-test was a multiple-choice test of grammar and reading comprehension. The reading passages comprised of grammar points that were presented in the textbook to be taught during the semester. They were carefully selected so as to correspond to grammar points as well as the topics of the units in the textbook. The test items were taken from the national university entrance exam (Konkoor) and the final exams of high school third grade. Both sources were recognizable enough to credit as they were tests of nation-wide scope. The reading passages were followed by 25 multiple-choice questions, based on the reading, and 15 grammar questions as well. The pre- test was not timed and the students had enough time to answer the entire test items. Of course, to reduce the probable effects of other irrelevant factors on the study, in addition to this pre-test, the researcher decided to include a control group into the study, too. All groups were at the same level concerning their English background, and all groups' performance was the same in the initial phase prior to the experiment. In this way, groups' homogeneity was ascertained and allowed for enquiry. In this way we could logically ascribe the failure or success of the activities on spelling skills.

\section{Post-test}

The same pre-test was administered as the post-test after a time interval of four months. There was no considerable test effect as the interval was long enough. Only a small number of the participants remembered to have taken the test before and so they could not logically be influenced by the pre-test. The results of the pre-test were statistically analyzed and led to the inference that the sample was homogeneous as far as their general English proficiency is concerned.

\section{The on-going quizzes}

After teaching every unit, a teacher-made test based on the same unit was administered. In designing these tests, the researcher made use of both inside the text materials and outside resources. All these four quizzes were designed and developed in this way to make sure of an optimal validity.

\section{The questionnaire}

In addition to the tests introduced earlier, the researcher made use of a questionnaire in the study to assess the impressions and attitudes of the students concerning the use of grammar teaching techniques. The questionnaire contained 10 items with answers ranging from strongly disagree to strongly agree. This questionnaire was intended to measure and evaluate the attitudes of the participants in terms of the efficiency of the techniques in the views of the students.

\section{The final test}

At the end of the semester, a final test was administered to all groups. This was a researcher- made test with uniform way of administration and scoring. All groups were tested on the same test in exactly the same way and I used blind scoring procedure to make sure of an unbiased conclusion. The final test included both grammar items and reading comprehension section, too. The researcher intended to evaluate the effects of grammar teaching techniques on the learners' reading comprehension ability. Therefore, I included a reading comprehension part in the final test, too. Of course, 
it is to be mentioned that the pre-test (which was also the posttest) had reading comprehension items for the same purpose. These reading passages contained grammatical points presented in the units.

\section{Validity}

As there was no standard test for our purpose, the researcher developed a test. A battery of tests was implemented until the final version was attained. The initial test was a general English proficiency test. The pre-test was pilot studied to find any probable shortcomings and improve it. The test items were taken from the national university entrance exam (Konkoor) and the final exams of high school third grade. Both sources were recognizable enough to credit as they were tests of nation-wide scope. However, to achieve an optimum level of validity, the researcher consulted some experts in the fields. These were three experienced EFL teachers and four university instructors. They recommended some revisions and corrections which were applied to refine the test.

\section{Reliability}

According to Hatch and Farhady (1981), reliability is the extent to which a test produces consistent results when administered under similar conditions. In other words, reliability is the stability of the results in different measurements. Reliable test scores could be compared with each other in more than one occasion. An unreliable test could be compared to a plastic flexible ruler which measures a certain distance, in different occasions, but yields different measures. In this study the Cronbach's Alpha formula was used. The reliability in this study is measured to be .908 .

\section{RESULTS AND DiSCUSSION}

\section{A. The Pre-test and the Post-test}

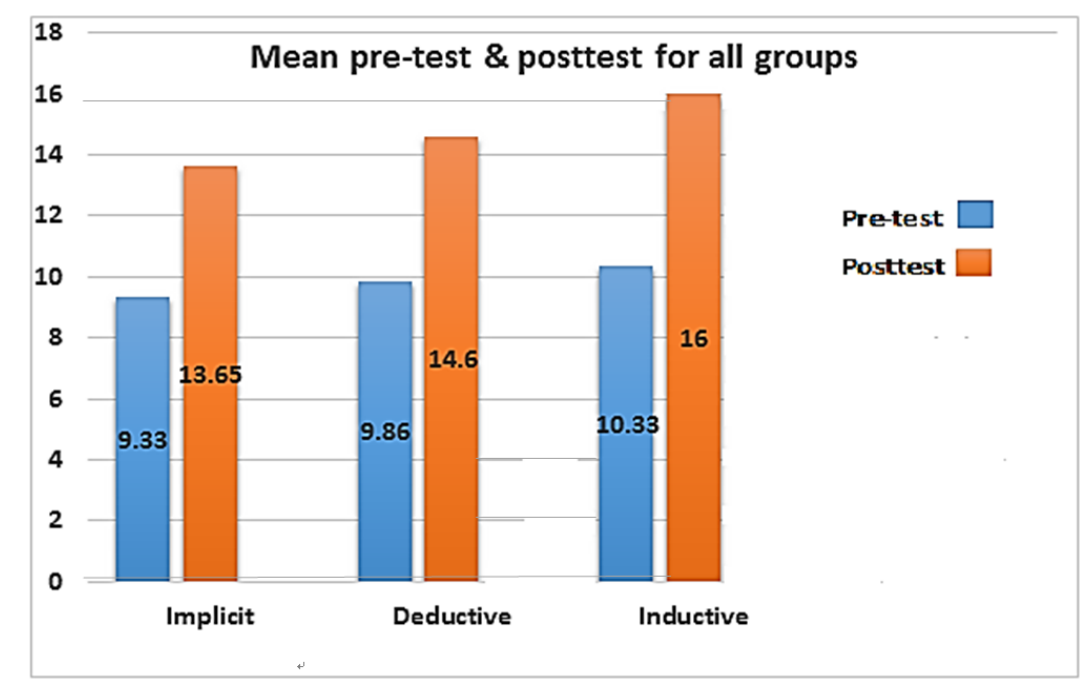

Chart 1. Mean scores in pre-test and posttest for all groups

The results obtained from comparing the mean scores in the pre-test and the post-test, emphasize the significant changes taken place as a result of applying the instructional techniques. They confirm the positive and favorable impact of these techniques on the performance of the students in the study. As the above chart indicates, the implemented techniques have led to changes and improvements in performance.

Concerning the efficiency of the techniques, as confirmed by the results of the tests, these strategies are all helpful and all enhance grammar skill; all of the three techniques significantly lead to a better performance, the degree of change, however, is not identical for all techniques. Based on the findings, it is clear that out of these three techniques, the Inductive technique is more effective.

\section{B. Quizzes}

After the pretest observation, three more tests (quizzes) were administered to all groups. As chart 2 shows, the inductive group has outperformed the other groups in all the three quizzes. 


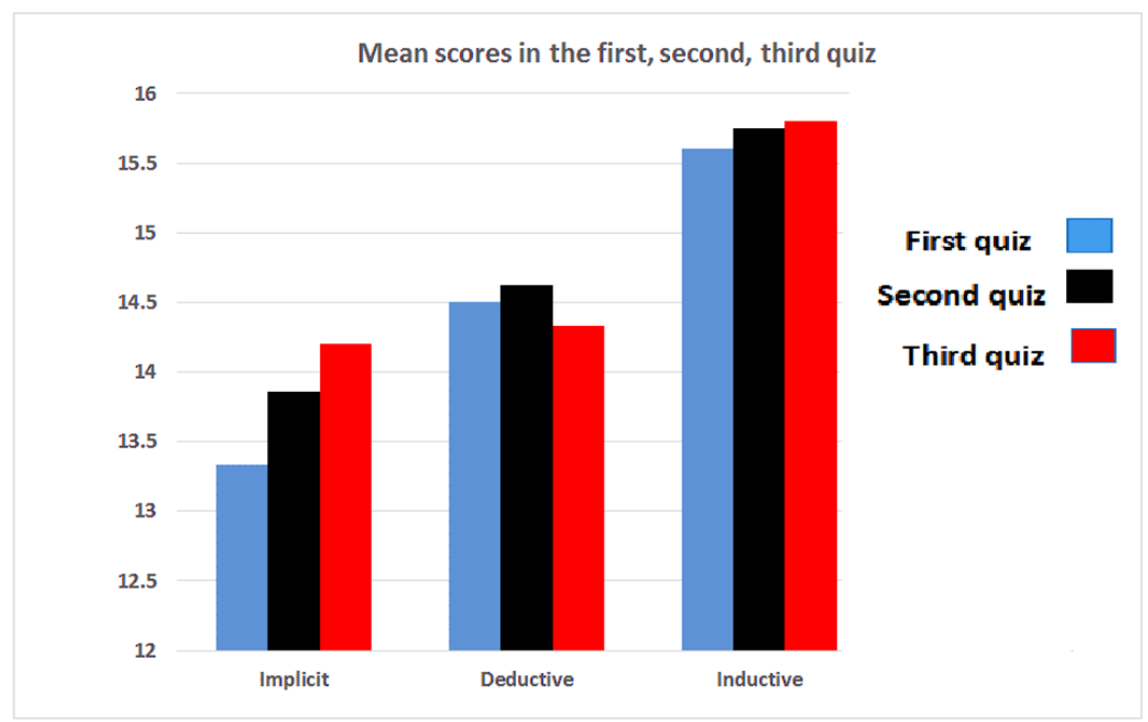

Chart 2. Comparing mean scores in three quizzes

These findings conform to the previous results; in the similar way, again, we can seek answer to the research questions in the study Thus, it could be concluded that the Inductive grammar teaching technique is, compared to other techniques, is more effective in bringing about the favorable change and improvement.

\section{The Final Test}

The analysis of the final test reveals the same results. The inductive group had better performance in the final test. The mean score in the inductive group is well above the other two groups. The deductive group placed in between the two groups, and the implicit group placed third in the final test. Thus it is recommended to be used in teaching grammar. Of course, the groups had similar performance in the reading comprehension section of the test. This was the opposite of what the researcher supposed before. Therefore, grammar instruction, based on the findings of the current study, could not affect the reading comprehension ability of the students and there may not be a direct link between reading and grammar knowledge. Of course, this point needs further research and investigation.

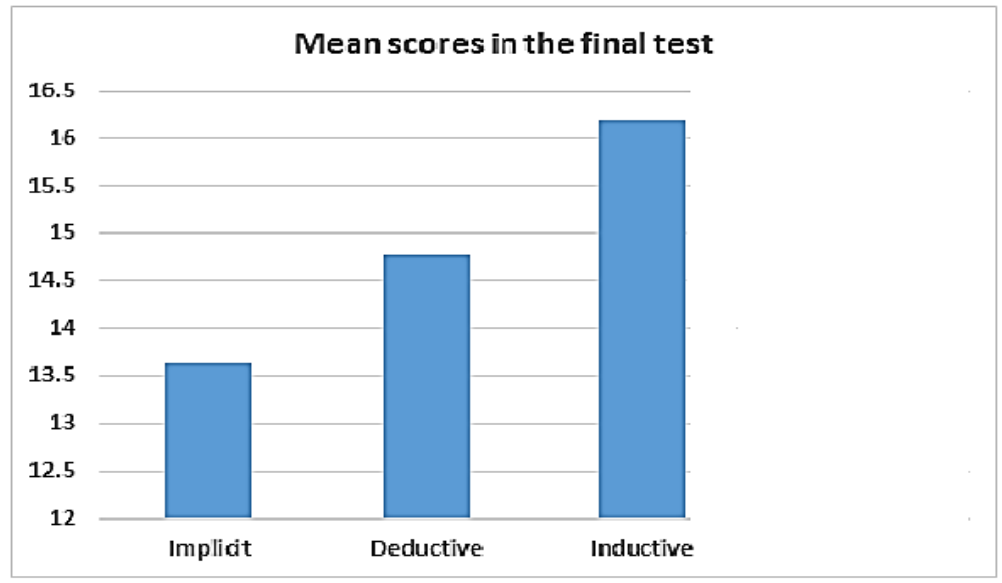

Chart 3 Mean scores in final test for all groups

\section{CONCLUSION}

\section{A. Findings}

This study intended to evaluate the efficiency of the grammar teaching techniques (the Implicit, the Deductive, and the Inductive techniques) on EFL college students. There were three research questions the answers to which formed the basis for the paper. This study was conducted with 80 college students, both boys and girls, who were divided into three experimental groups, for the three techniques.

The observation made as the pre-test, assured the researcher of the similarity and homogeneity of all three groups. The observation revealed that the students were at same level. All the participants in all groups made progress to a large extent. A comparison of the mean of the scores obtained from the post-test proves this progress and advancement. 
An important finding of the study concerns the impacts of grammar teaching and the reading comprehension skill. These findings indicate that grammar and reading are not related together, as opposed to what the researcher supposed prior to the study. The researcher included the reading part to investigate the impact of grammar instruction on the reading comprehension ability of the learners. In this study, it was observed that grammar teaching has very little, if any, influence on comprehension. The researcher was surprised to know the fact and by no means could imagine the possibility of the very finding.

\section{B. Applications and Implications}

It seems that grammar is treated on an all or nothing basis depending the orientation of the instructor. In some cases grammar teaching is profoundly overemphasized and in other cases it is completely ignored. However, teaching grammar necessitates its own specialty and deserves its own special position in the curriculum. Familiarity with the theories involved in grammar instruction and designing appropriate activities and tasks to contextualize the point is a great concern.

In the present study, there were three research questions and hypotheses. Based on the findings in the study, it could be concluded that the inductive techniques led to a more effective instruction and yielded better results than the other techniques. As for teachers, they could improve their own presentation and teaching and their students' reading and grammar skill through the effective use of instructional techniques.

The results of the study can potentially change EFL teachers' attitudes about the nature of grammar. They can utilize suitable grammar techniques and can help their students by providing opportunities for the students to use these spelling techniques in practice in real situations. The role of EFL teacher is all important in this respect. He can make up for the shortcomings in the course books through his own experience and the provision of effective techniques (Hashemi and Ghalkhani, 2016).

Material developers, syllabus designers, parents, and all those involved in teaching and learning, can make use of these findings for providing better conditions for learning and teaching. Providing students with modern methods and techniques for learning is undoubtedly a great thing; we can help them to read effectively and have better comprehension and enjoy reading as fun (Hashemi, Mobini and Karimkhanlooie, 2016).

\section{Suggestions for Further Research}

In the present study, some variables such as gender were not taken into account. Further studies can focus on the role of gender in grammar instruction. Future research, also can focus on other aspects of language and explore the efficiency of such techniques on other language skills, i.e., listening, speaking, and writing.

Future research can investigate the link between grammar and reading comprehension. As stated above, we could find no relationship between grammar and reading skill, and this could be further studied to correct or modify this conclusion.

\section{REFERENCES}

[1] Brown, H. (2000). Principles of language learning and teaching (4th ed.). New York: Addison-Wesley Longman, Inc.

[2] Brown, H. D. (1994). Teaching by principles: An integrative approach to language pedagogy. Englewood Cliffs, NJ: Prentice Hall Regents.

[3] Celce-Murcia, M. (1991). Grammar pedagogy in second and foreign language teaching. TESOL Quarterly, 2J, 459-480.

[4] Chang, Shih-Chuan (2011). A Contrastive Study of Grammar Translation Method and Communicative Approach in Teaching English Grammar. English Language Teaching Vol. 4, No. 2; June 2011. Pp 13-25

[5] Chomsky, N. (1957). Syntactic Structures. The Hague: Moulton.

[6] Cook, V. (1994). Universal Grammar and the learning and teaching of second languages. In T. Odlin \{Ed.\}, Perspectives on pedagogical grammar (pp. 25-48). Cambridge, UK: Cambridge University Press.

[7] Corder, S. (1988). Pedagogic grammar. In W. Rutherford \& M. Sharwood-Smith (Eds.), Grammar and second language teaching (pp. 123-145). New York: Harper \& Row Publishers, Inc.

[8] Crystal, D. (1997). A Dictionary of Linguistics and Phonetics (4th ed.). Blackwell: Blackwell Publishing.

[9] Crystal, David (1995). The Cambridge encyclopedia of the English language. Cambridge: Cambridge University Press.

[10] Doff, A. (2000). Teach English: A training course for teachers (14th ed.). Cambridge: Cambridge University Press.

[11] Ellis, R. (2001). Investigating form-focused instruction. In R. Ellis (Ed.), Form-focused instruction and second language learning (pp. 1-46). Malden, MA: Blackwell.

[12] Ellis, R. (2004). The definition and measurement of L2 explicit knowledge. Language Learning, 54, 227-275

[13] Ellis, R. (2006), Current Issues in the Teaching of Grammar: An SLA Perspective. TESOL Quarterly 40, 83-107.

[14] Ellis, R. (I 996). The study of second language acquisition. Oxford: Oxford University Press.

[15] Fortune, A. (1992). Self-study grammar practice: Learners views and preferences. ELT Journal 46(2), 160-171.

[16] Hashemi, Ali, and Omid Ghalkhani. (2016). "The Impact of Different Teaching Strategies on Teaching Spelling to Kindergarten Children", Journal of Language Teaching and Research.

[17] Hashemi, Ali, Mobini, Fariba, and Karimkhanlooie, Guiti. (2016). The impact of content-based pre-reading techniques on Iranian high school EFL learners' reading comprehension. Journal of Language Teaching and Research, Vol. 7, No. 1

[18] Herron, C. (1976). An investigation of the effectiveness of using an Advance Organizer in the foreign language classroom. Modern Language Journal, 78, 190-198.

[19] Howatt, A. (19\$4). A history of English language teaching. Oxford: Oxford University Press.

[20] Klein, W. (1986). Second language acquisition. Cambridge: Cambridge University Press. 
[21] Krashen, S. (1987). Applications of psycholinguistic research to the classroom. In M. Long \& J. Richards (Eds.), Methodology in TESOL (pp. 33-44). New Jersey: Heinle \& Heinle Publishers.

[22] Krashen, S. D. (1987). Principles and practices in second language learning. New York: Prentice-Hall

[23] Krashen, S., \& Terrell. T. (1983). The natural approach: Language acquisition in the classroom. New York: Pergamon.

[24] Larsen-Freeman, D. (1991). Teaching grammar. In M. Celce-Murcia (Ed.), Teaching English as a second or foreign language (2nd ed., pp. 279-295). Boston: Heinle and Heinle.

[25] Larsen-Freeman, D. (2000). Techniques and principles in language learning (2 ed.). Oxford: Oxford University Press.

[26] Larsen-Freeman, D. (2009). Teaching and testing grammar. In M. Long and C. Doughty (Eds.). The Handbook of Language Teaching. Malden, MA: Blackwell.

[27] Larsen-Freeman, D., and Long, M. H. (1991). An introduction to second language acquisition research. New York: Longman

[28] Long, M. H. (1983). Does second language instruction make a difference? A review of the research. TESOL Quarterly, 17, 359-382.

[29] Long, M., \& Crookes, C. (1992). Three approaches to task-based syllabus design. TESOL Quarterly. 26. 27-56.

[30] Long. M. (1991). Focus on form: A design feature in language teaching methodology. In K. de Bot, D. Coste, R. Ginsbetg. \& C. Kramsch (Eds.). Foreign language research in cross- cultural perspectives (pp. 39-52). Amsterdam: John Benjamins.

[31] Norris, J., \& Ortega, L. (2000). Effectiveness of L2 instruction: A research synthesis and quantitative meta-analysis. Language Learning, 50, 417-528.

[32] Nunan, D. (2003). Practical English Language Teaching. $1^{\text {st }}$ ed. America: New York: McGraw-Hill companies.

[33] Penny, R. (2000). Variation and change in Spanish. Cambridge: Cambridge University Press.

[34] Purpura, James E. (2004). Assessing grammar. Cambridge University Press, Cambridge, U.K.; New York

[35] Richards, J. C. (1992). Longman Dictionary of Language Teaching and Applied Linguistics. Longman: Longman University Press.

[36] Richards, J., \& Rodgers, T. (2001). Approaches and methods in language teaching ( $2^{\text {nd }}$ ed.). Cambridge: Cambridge University Press.

[37] Rutherford, W. (1987). Second language grammar learning and teaching. New York: Longman.

[38] Scarcella, R. (2003). Accelerating academic English: A focus on the English learner. Oakland, CA: Regents of the University of California.

[39] Schmidt. R. (1990). The role of consciousness in second language learning. Applied Linguistics, 11, 129-158.

[40] Schmidt. R. (1993). Awareness and second language acquisition. Annual Review of Applied Linguistics, 13, $206-226$.

[41] Sharwood Smith, M. (1993). Input enhancement in instructed SLA: Theoretical bases. Studies in second language acquisition. 15, 165-I 79.

[42] Skehan. P. (1996). A framework for the implementation of 'task-based instruction. Applied linguistics, 17. 38-62.

[43] Skehan. P. (1998). A cognitive approach to language learning. Oxford: Oxford University Press.

[44] Swain, M. (1985). Communicative competence: Some roles of comprehensible input and comprehensible output in its development. In S. Gass \& C. Madden (eds.), Input in second language acquisition (pp. 235-53). Rowley, MA: Newbury House.

[45] Thornbury, S. (2003). How to Teach Grammar. Beijing: World Affairs Press.

[46] Ur, P. (1999). Grammar practice activities: A practical guide for teachers (12 ed.). Cambridge: Cambridge University Press.

[47] Van Patten, B. (2004). Input processing in second language acquisition. In B. Van Patten (ed.), Processing instruction: Theory, research, and commentary (pp. 5-31). Mahwah, NJ: Lawrence Erlbaum.

[48] Wales, K. (2001). A Dictionary of Stylistics. London, New York, Reading, San Francisco: Pearson Education Longman.

[49] White, L. (1987). Against comprehensible input: The input hypothesis and the development of second-language competence. Applied Linguistics 8, 2, 95-110.

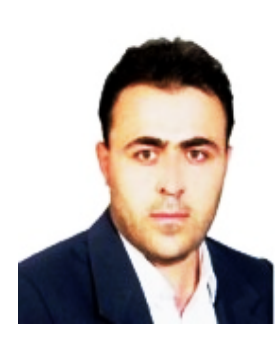

Ali Hashemi is a Ph.D. candidate in TEFL. He is an experienced English teacher and head of ELT board at Zanjan, Iran. The author is currently teaching at high schools. He also works as an instructor at Payam Noor University, Islamic Azad University, and Applied Science Center. He teaches both general English as well as some ESP courses on a variety of fields. His fields of interests include: language skills, ESP material development, and teacher education.

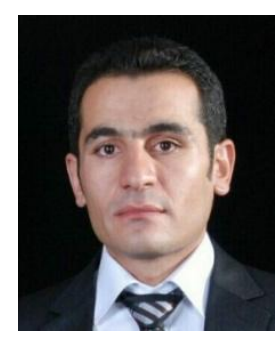

Samran Daneshfar was born in Piran Shahr, Iran. He is an MA graduate of the University of Zanjan, Iran in TEFL. He is currently an experienced EFL teacher in Ministry of Education in Piran Shahr. He is teaching at junior high school. His areas of interest are the Sociocultural Theory and Dynamic Assessment in second language. 